\section{Testing-time for British industry both at home and abroad}

THE year ahead in Britain will be memorable for the energy the government will spend exhorting British industry to mend its ways. Britain must think internationally, its research effort must be directed towards more commercial goals and its development budget must be substantially increased - by industry, not the taxpayer. That will be the message, based on lessons bitterly learned last year: British innovation, conspicuously less successful than that in Japan and the United States, is now also compared unfavourably with that elsewhere in Europe. There will also probably be a general election.

The lessons learned by Britain's General Electric Company (GEC) in the last two weeks of 1986 starkly typify the problem. The Ministry of Defence has been in the market for an airborne early warning radar system since 1978, since when GEC has spent $£ 900$ million on the development of a system called Nimrod. But in the event, on the advice of the Royal Air Force and other technical advisers, the government has chosen to buy the Boeing AWACS system instead.

This shaming development has confirmed the government in its view that British industry is too parochial, that its attempts to exploit research are sluggish and that research efforts in university and commercial laboratories are not properly coordinated. GEC's painful lesson will be repeated again and again this year at the hands of a government convinced that it spends too much on research and has too little to show for it.

To steer Britain in the right direction, the government plans to create a completely new mechanism, the first element of which will involve a team of industrialists, academics, financiers and bureaucrats charged with hammering out a new policy on industry and research. The foundations of this structure, unlike any previously attempted in Britain, will be laid by the spring by its chief architects, the team of scientific advisers at the Cabinet Office under the govenrment's chief scientific adviser John Fairclough.

By the end of the year, there will also be new procedures to ensure that the funds spent through the Advisory Board for the Research Councils have the effect of concentrating research more effectively on selected centres. The Cabinent Officer believes that this strategy will ensure the existence of well-equipped centres of excellence capable of competing internationally.

Research and development in information technology may well benefit specifically this year. Much will depend on the government's response to the demand of Bide (retired chairman of Glaxo) for an investment of $£ 1,000$ million over five years, half of it from public funds. Bide is bullish, predicting a positive response. His plan is for a continuation of the five-year Alvey programme of research in information technology, perhaps incorporating the British contribution to the European Commission's ESPRIT initiative.

But 1987 will also be a year in which Britain discovers that internationalism does not come cheap. Officials of the British National Space Centre (BNSC) are still waiting for the government's approval of their 15-year plan, which would entail an annual commitment of $£ 200$ million, most of it for collaborative projects through the European Space Agency (ESA). While the government pontificates about the insularity of British research and the lack of an international vision in industry, it has itself been rather slow to respond to this latest international opportunity.

In another field, the government's international pretensions will be tested as

\section{Prospects for 1987 United Kingdom Bill Johnstone in London}

the European states prepare to launch the first Direct Broadcasting Satellites (DBS), Earth satellites broadcasting television signals strong enough to be picked up by individual homes equipped with small antennas. The Independent Broadcasting Authority (the licensing authority for commercial television and radio) has at last awarded a franchise to operate three DBS channels. That dubious prize, which could cost $£ 700$ million over 15 years, has gone to British Satellite BroadConsumer Electronics (a prominent hi-fi and microcomputer supplier), the Anglia and Granada commercial television stations, the Pearson Group (owners of the Financial Times among other things) and the Virgin Group (the record company that recently founded an airline).

There are potential disputes ahead over European programming policy. The European Commission's proposal that DBS should carry a specified minimum proportion of material of European origin has been contested by European states. It remains to be seen whether what will emerge from a meeting of the Council of Europe last December will be more acceptable, and whether any agreement can be policed.

Meanwhile, both France and West the IT86 Committee, under Sir Austin casting (BSB), a consortium of Amstrad
Germany are to launch in the next 12 to 18 months their own DBS services, assisted by generous grants from their governments. It will be possible to receive these services in the British Isles long before the British system, due for launch in 1989-90, is in service.

Another contentious issue in Britain will be that of who builds the satellite for the BSB consortium. Five years ago, the British Broadcasting Corporation (BBC) together with a group of television and industrial companies, won a licence to op-

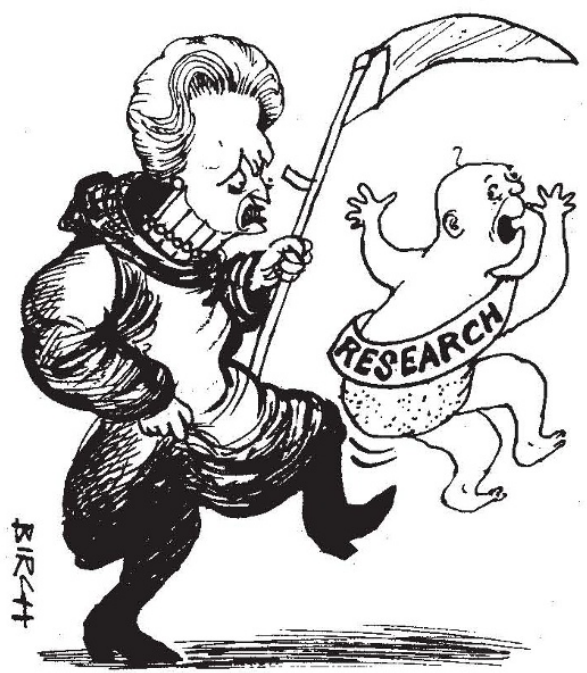

erate a DBS system, arranged to buy three satellites from a consortium consisting of British Aerospace, GEC-Marconi and British Telecom (the denationalized telecommunications company) and then aborted the project on the grounds of cost. Now, Comsat and RCA will be prominent bidders for the satellites that BSB will need. British industry, not for the first time, may find itself bested by the United States.

During 1987, Britain may also finally decide its long-term relationship with the European Organisation for Nuclear Research (CERN), the high-energy physics laboratory at Geneva.

Britain last year declared its wish to reduce its contribution to CERN (which reached $£ 37.56$ million in $1985-86$ ) by 25 per cent before 1991, for which reason an internal review committee has been established to work out whether the British wish can be accommodated. But the declining value of sterling has since made membership even more expensive; virtually all the extra $£ 20$ million for research won from the government towards the end of last year will need to go to CERN. Action of some kind, perhaps drastic, is likely once the internal review is complete.

On CERN as in other matters, the government will have the final say. Will it throw in its hand on CERN for the sake of spending a little on space? Or, in an election year, will it find that there is enough to do both? A little time should provide the answer. 